\title{
Small(pox) success?
}

\section{Erradicação da varíola: medida do sucesso?}

Anne-Emanuelle Birn ${ }^{1}$

\begin{abstract}
The $30^{\text {th }}$ anniversary of the World Health Organization's (WHO) official certification of smallpox eradication was marked by a slew of events hailing the campaign's dramatic tale of technological and organizational triumph against an ancient scourge. Yet commemorations also serve as moments of critical reflection. This article questions the acclaim showered upon smallpox eradication as the single greatest public health success in history. It examines how and why smallpox eradication and WHO's concurrent social justice-oriented primary health care approach (following from the Declaration of Alma-Ata) became competing paradigms. It synthesizes critiques of eradication's shortcomings and debunks some of the myths surrounding the global eradication campaign as a public health priority and necessity, and as a Cold War victory of cooperation. The article concludes with thoughts on integrating technical and social-political aspects of health within the context of welfare states as the means to achieving widespread and enduring global public health success.
\end{abstract}

Key words Smallpox eradication, WHO, Halfdan Mahler, Global health, Alma-Ata
Resumo $O 30^{\circ}$ aniversário da certificação oficial da Organização Mundial da Saúde (OMS) da erradicação da varíola foi marcado por uma série de eventos que saudaram a dramática história do triunfo tecnológico e organizacional contra este antigo flagelo. Todavia, as comemorações também servem como momentos para uma reflexão crítica. Este artigo questiona os aplausos excessivos para a erradicação da varíola como o único e absoluto sucesso na história da saúde pública. Examina como e por que a erradicação da varíola e a abordagem da atenção básica de saúde orientada para a justiça social (de acordo com a Declaração de AlmaAta) se tornaram paradigmas concorrentes. Sintetiza críticas sobre as deficiências da erradicação e busca desvelar alguns dos mitos que envolvem a campanha de erradicação global como uma prioridade e necessidade da saúde pública, e como uma vitória da cooperação da Guerra Fria. O artigo finaliza com reflexões sobre a integração de aspectos técnicos e sociopolíticos da saúde no contexto do Estado de bem-estar social como forma de atingir um amplo e duradouro sucesso para a saúde pública global.

Palavras-chave Erradicação da varíola, OMS, Halfdan Mahler, Saúde global, Alma-Ata
${ }^{1}$ University of Toronto. 155 College St., Room 558. Toronto, ON M5T 3M7,

Canada.

ae.birn@utoronto.ca 


\section{Introduction}

According to standard institutional accounts, the eradication of smallpox offers a dramatic tale of technological and organizational triumph over naysayers and of the single greatest public health success in history - marking pride among lead international health agencies and rank-and-file health workers alike - and even of an unlikely victory of Cold War cooperation ${ }^{1-4}$. On this $30^{\text {th }}$ anniversary of the World Health Organization's (WHO) official certification of smallpox eradication, only a curmudgeon, it would seem, could find a downside to this quintessential global public health parable.

Yet in 1980, WHO's then Director-General Halfdan Mahler portended such a less-than-heroic appraisal by declaring: Important lessons can be learned from smallpox eradication - but the idea that we should single out other diseases for worldwide eradication campaigns is not among them. That idea is tempting but illusory ${ }^{5}$ (p. xii).

Why did Mahler make this assertion, what were its effects, and what are the implications for global/international health today?

Mahler's stated reason was that smallpox's epidemiology (that is, its exclusive human-human means of transmission) was "unlike that of any other disease"5 (p. xii). He offered passing praise for the dedication of national and international smallpox campaign staff, the technological and scientific research leading to easy-to-use bifurcated needles and freeze-dried vaccine, and for the role of epidemiological, social, and health services research to ensure the efficiency and effectiveness of surveillance and control activities.

But his subtext was patent: the declaration of smallpox eradication - although "heralding the triumph of an aspiration" - was a distraction from the almost simultaneous Declaration of Alma-Ata, which itself was the very "embod[iment] [of] an aspiration" that was "likely to change the course of worldwide efforts for health"5 (p. xi) on the part of WHO and the international health community.

For Mahler it was Alma-Ata's "stirring of an international health conscience" together with its "technical content, its demand for social justice in health matters" and its principles for formulating primary health care (PHC) policies together with a range of social and economic measures, that offered "clear indications" for global health ${ }^{5}$ (p. xi). Not only were smallpox eradication and primary health care in uncomfortable co-existence in Mahler's biennial report and in their simulta- neous unfolding at $\mathrm{WHO}^{6}$, they represented the longtime and fundamental contested ideological basis for (international) public health activities: narrow, technically-oriented, top-down (vertical) approaches to disease versus broad, integrated, participatory (horizontal) approaches to health ${ }^{7}$.

Mahler's views about smallpox eradication, of course, did not end global eradication campaigns, but they may have forestalled them. The World Health Assembly (WHA) did not vote to launch another eradication campaign (against polio) until May 1988, just two months before Mahler's announced retirement took effect. At the time, Mahler's closest advisor, Joshua Cohen, recommended that the resolution call for polio to be "eliminated" rather than eradicated, due to the existence of wild poliovirus. However, the WHA's enthusiasm for a repeat success of eradication outvoted the cautionary approach, which has since proven prescient ${ }^{8}$. To be sure, former smallpox staff became involved in a guinea worm eradication effort, begun in 1986, but that has been based out of the Carter Center in Atlanta, USA, rather than at WHO (and endorsed by a WHA resolution only in 1991). The International Measles Initiative was created in 2001, but the WHA has only committed itself to supporting targets towards eventual eradication, rather than eradication per se. A variety of other programs to eliminate or combat diseases are in place or under consideration.

Even though eradication per se was not on the international health agenda, Mahler and proponents of primary health care within and beyond WHO would spend much of the 1980s in defensive mode against "selective primary health care" (SPHC) $)^{9,10}$. Most prominently realized in the reductionist "child survival revolution," spearheaded by Unicef ${ }^{11}$, SPHC has been understood as a verticalization of primary health care ${ }^{12}$ that echoed smallpox's targeted approach and overlooked social, political, infrastructural and health conditions writ large ${ }^{13}$.

Certainly many elements of Unicef's now (in)famous GOBI-FFF (growth monitoring, oral rehydration, breastfeeding, immunization and family planning, female education, food supplementation) approach - particularly Unicef's support for WHO's Expanded Program on Immunization and diarrheal disease control efforts - were administered as vertical campaigns, and Unicef's donor-driven approach left little room for local agenda-setting. But other elements merit further consideration. Unicef was instrumental in shaping both the 1978 Alma-Ata International Con- 
ference on Primary Health Care ${ }^{14}$ and the 1981 International Code of Marketing of Breastmilk Substitutes, which called for an end - worldwide - to the unethical marketing of infant formula and other commercial baby foods that may lead to displacement of breastmilk. Unicef was involved in the monitoring and implementation of the Code, as well as in promoting breastfeeding in its country efforts, pitting it against powerful baby food manufacturers ${ }^{15,16}$. This made Unicef, like WHO, subject to fierce attacks by the influential conservative US thinktank, The Heritage Foundation $^{17,18}$. Through these years, Unicef also supported the essential drugs program, development of district health systems, and other components of joint PHC initiatives implemented with WHO, even as GOBI-FFF activities dominated its efforts.

Did smallpox eradication destroy any hopes for a participatory, integrated, social-justice-oriented PHC approach or were other factors at play? The frequent Unicef/WHO Intersecretariat and Joint Committee on Health Policy meetings of the 1980s do not seem to have explicitly discussed smallpox eradication, but the topic may have been implicitly present ${ }^{19,20}$. More than drawing from smallpox eradication as a model of success, however, SPHC's promise of cost-effectiveness flourished in the 1980s context of tight budgets and the ascendant dominance of AngloAmerican pro-corporate, neo-conservatism (later neoliberalism).

In that sense, Mahler's concern that the very fact of smallpox success would be a deterrent to PHC was overstated. Far more important in obstructing PHC was the larger political-ideological shift in key Western bloc societies in conjunction with the economic crisis of the early 1980s.

\section{Wherefore smallpox eradication?}

Several myths have re-surfaced in the marking of thirty years of smallpox eradication. One is that the USSR and US worked together to create a paragon of Cold War cooperation ${ }^{21,22}$. But it is worth questioning whether the joint global (health) agenda set by the rivals further entrenched the Cold War rather than transcending or interrupting it in the name of world health. More than anything, the campaign demonstrated the respective strengths of the giants - largescale vaccine production on the part of the Soviets and organizational knowhow on the part of the Americans ${ }^{23}$ - vastly overshadowing the role of other important but smaller players such as
Canada and Scandinavian countries. Was this an expression of generosity on the part of superpowers or of geopolitical self-interest? When compared to the courageous efforts of those involved in International Physicians for the Prevention of Nuclear War ${ }^{24}$ - and the very real health implications of nuclear war between the superpowers - the Cold War cooperation aspect of smallpox seems much diminished.

It is also important to note that - while a clear candidate for technical (feasibility), donor (Soviet and American support), and institutional (following WHO's previous malaria eradication failure) reasons - smallpox was an odd choice on public health priority grounds. At the launch of the campaign, smallpox incidence and mortality had already been declining for many decades thanks to effective national use of the vaccine. Outside of South Asia, certain countries in Africa, and a few other settings, smallpox was not an important health problem.

The Rockefeller Foundation - which invented the very idea of a disease eradication campaign with its 1910-1914 hookworm campaign in the South of the U.S. - held little interest in smallpox, though it was engaged in campaigns against yellow fever in Latin America, malaria in Sardinia and (at least imported malaria) in Brazil, among a variety of other disease eradication efforts. For example in Mexico, the Rockefeller Foundation spent just US\$1660 (real dollars) on smallpox control out of some US\$7.3 million (real dollars) total expenditures for field programs in Mexico between 1920 and $1941^{25}$ (p. 244-245).

Before World War II, smallpox vaccination was both routine and widespread. In most countries, smallpox vaccination typically became mandatory in the $19^{\text {th }}$ century, once the effectiveness, relative safety, and political advantages of a vaccinated population became apparent. Implementation of this policy was interrupted by anti-vaccination campaigns in various settings ${ }^{26-28}$ but vaccination prevailed by the early $20^{\text {th }}$ century. Uruguay, for example, began government administration of smallpox vaccination in 1836, just six years after its independence. By 1908, two thirds of the country's population, and almost 90 percent of the capital's, had been vaccinated according to the 1908 census. In 1910, when a senior Board of Hygiene official was infected with smallpox while carrying out a rural hygiene inspection and subsequently died, the country redoubled its vaccination efforts, making vaccination obligatory and re-vaccinating much of the population ${ }^{29}$, just as New York City did 37 years later. 
Indeed, wherever welfare states had begun to develop - reflecting struggles for a range of societal (including health) protections throughout the Americas, Europe, and beyond - smallpox vaccination, together with other effective public health measures from diphtheria anti-toxin to garbage collection, proliferated.

Undoubtedly, in the post-colonial settings where endemic smallpox was most problematic $c^{30}$ in the 1950s and 1960s, these struggles were just beginning, as subjects-turned-citizens began to make claims on newly independent states. But to say that it was only after the World Health Organization's decision to eradicate smallpox in 1966, did the world begin to rid itself of this ancient scourge ${ }^{31}$ (p. iii), as does a just-published comic book sponsored by the Smallpox Eradication Commemoration 2010 Secretariat, is a gross misstatement.

Indeed, it might be argued that smallpox was still killing two million people per year in the 1960s "not because" the world lacked a global eradication program "but because" existing effective measures were not sufficiently administered in settings plagued by underdevelopment, the legacies of imperialism, poverty, inequality, and inadequate health systems infrastructure.

\section{The downside of eradication}

Disease eradication efforts have been critiqued on a number of grounds:

. they skew priorities, making local and national needs secondary to global eradication aims;

. they typically require enormous "recipient" country spending, with countries enjoined to commit significant resources in the name of "international solidarity" (p. 1230) and/or "recipient countries" are subject to aid conditionalities and unfair incentives;

- they reinforce technical, disease-based approaches that do little to address overall health or well-being;

. they disregard the underlying and shared social etiology of most diseases and miss the synergistic potential of addressing the social determinants of health (imagine the futility and wasted resources of hundreds of simultaneous disease eradication/control programs);

. they can backfire: coercion may be needed to achieve goals, generating mistrust, not just against the campaign but against other public health efforts ${ }^{32,33}$;

. they may not coordinate with health systems and national and local authorities, leaving infrastructure to deteriorate ${ }^{34,35}$;
. for the vast majority of diseases, feasibility is highly questionable (for example the Global Malaria Eradication campaign excluded Africa for this reason from its very beginning ${ }^{36}$ );

. they miss opportunities to prevent and/or treat other problems (the Rockefeller Foundation noted this with its multi-country hookworm campaigns in the 1910s and 1920s, in which RF officers had to disregard other, often far more serious, health conditions in order to meet hookworm treatment targets ${ }^{25}$ [p. 61-116]).

Even disease-eradication gurus concur with some of these critiques ${ }^{37-39}$. But the most persistent and powerful driver of disease eradication is its putative cost-effectiveness and large net benefit yields $s^{40}$. Regarding smallpox eradication, Mahler himself noted, "Here is a cost/benefit success story if there ever was one!"5 (p. xii). D.A. Henderson, the former director of the smallpox campaign, and his colleagues argued that the total US\$313 million expenditure over ten years of the campaign (over $\$ 1$ billion today) was the best global health investment ever, calculating that the eradication of smallpox saves the world's governments more than \$USD 1 billion annually, indefinitely, in reduced productivity losses and medical care costs ${ }^{1}$, augmented by indirect savings from averted deaths, and cases of blindness, and other disabilities.

But such a cost-benefit analysis is unfair: the low-income countries where smallpox was endemic footed approximately two thirds of the smallpox campaign bill, but most of the benefits are reaped by affluent countries where the cost of administering routine smallpox vaccination is far higher. Moreover, the smallpox campaign expenditures employed in cost-benefit analysis do not take into account the opportunity costs - the displacement of spending on the part of the WHO and participating countries away from housing, nutrition, health infrastructure, sanitation, and other health-enhancing arenas.

The historical record supports Mahler's cautionary: the success story will have a punch-line only if the governments of these countries decide to plough back the money they have saved into other activities for attaining world health ${ }^{5}$ (p. xii). Mahler invoked this idea again and again. When member countries were in arrears, he reminded them that the savings accrued due to smallpox eradication had earned them back all of their WHO membership contributions since 1948 plus interest $^{41}$. Yet smallpox eradication did not stimulate such a commitment either to WHO or to world health ${ }^{42}$ : overseas development aid stagnated through the 1980s, with health conditions in de- 
veloping countries taking an especially hard hit due to the forced disinvestment in health, education, and social services as part of the structural adjustment policies imposed by the World Bank and the International Monetary Fund in many low-income countries ${ }^{43}$.

The tide seems to be turning away from exclusive disease eradication approaches as a model for global health. The polio eradication effort has long bypassed the cost and time required by smallpox eradication. Twenty-two years into the campaign, almost \$USD 10 billion has been spent, and the presence of wild poliovirus or resurgence in countries from Nigeria to Tajikistan have led to considerable re-evaluation of polio eradication. Even mega-philanthropist Bill Gates, one of the largest proponents of, and donors to technical approaches to global health ${ }^{44,45}$ (including close to US\$1 billion for polio eradication), has belatedly begun to understand that targeted eradication needs to be integrated with broader health infrastructural approaches ${ }^{46}$.

\section{What now?}

The (international) public health field has been notoriously inept at promoting its role in the improvement of health and life expectancy (especially as compared to medicine). Milk pasteurization, housing, access to clean water and sanitation improvements, food and occupational safety, social

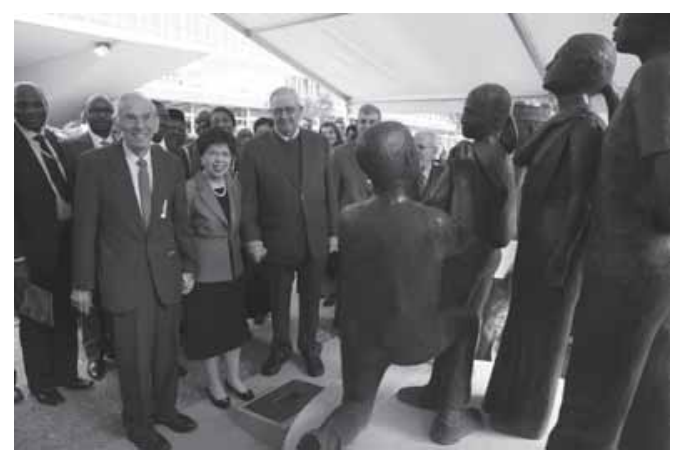

Figure 1. From left to right: the former DirectorGeneral of WHO, Dr. Halfdan Mahler; current WHO Director-General, Dr. Margaret Chan; and Dr. Donald A. Henderson, the former chief of the Smallpox Eradication Unit at the unveiling of a statue commemorating the 30th aniversary of the eradication of smallpox, May 2010.

Photo by Jess Hoffman. Courtesy of WHO. security measures, to cite just a few examples, are rarely claimed as public health successes.

If we are able to resuscitate these successes, then why deny smallpox eradication a place in international public health's hall of fame? But in doing so, let's be fair by showcasing the differing routes to ending smallpox: targeted campaigns carried out in considerable isolation of other efforts versus integration of smallpox vaccination into expanding welfare states (with targeted campaigns as needed).

Thirty years after the declaration of smallpox eradication, D.A. Henderson and Halfdan Mahler came together in May 2010 for a ceremony to inaugurate a smallpox campaign statue at WHO headquarters in Geneva (Figures 1 and 2).

If the respective icons of smallpox eradication and primary health care could meet despite acerbic words in the past, perhaps this is a moment for a productive end to the dichotomized debate between vertical and horizontal approaches to health. Why not back targeted efforts within universality and the integration of BOTH technical and socio-political approaches? Sound familiar - perhaps because it echoes the Alma-Ata declaration...

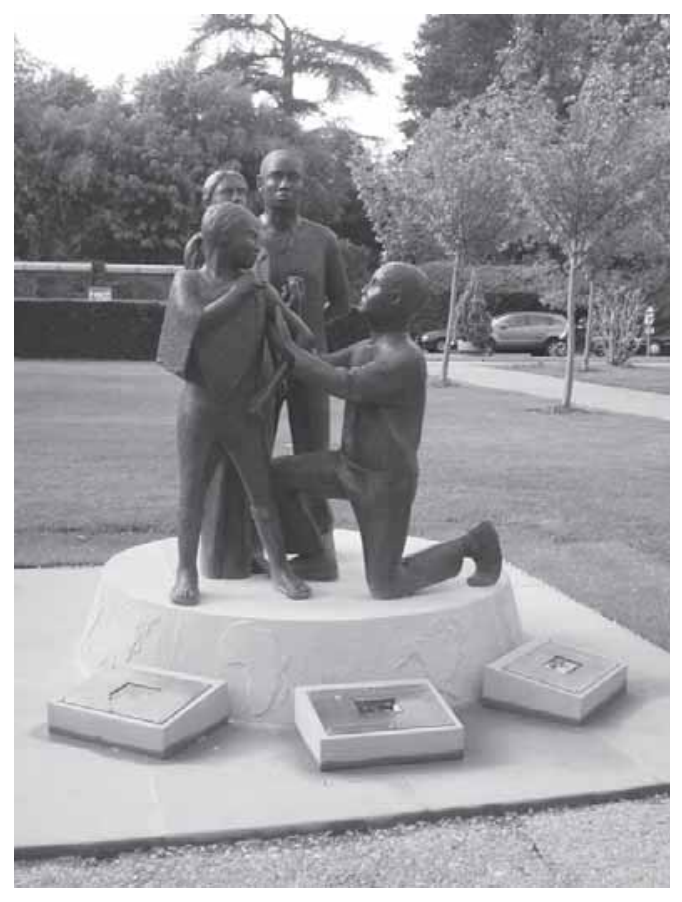

Figure 2. Statue commemorating the 30th aniversary of the eradication of smallpox in front of WHO headquarters.

Photo by Anne-Emanuelle Birn. 


\section{Acknowledgements}

I am grateful to Gilberto Hochman and to Lida Lhotska for their stimulating and useful suggestions. Funding for the research and writing of this paper was provided by the Canada Research Chairs Program. This funder had no other role in the writing of the paper or in the decision to submit for publication, and the ideas expressed herein are mine alone. No conflicts of interest are declared, but I was vaccinated against smallpox as an infant in Helsinki and re-vaccinated as a child in Toronto and Washington D.C.

\section{References}

1. Fenner F, Henderson DA, Arita I, Jezek Z, Ladnyi ID. Smallpox and its eradication. Geneva: WHO; 1988.

2. Gates B. Prepared remarks to the 2005 World Health Assembly. Seattle: Bill and Melinda Gates Foundation; 2005. [artigo na Internet] 2005 [acessado 2010 jun 12]. Disponível em: http://www.gatesfoundation. org/speeches-commentary/Pages/bill-gates-2005world-health-assembly.aspx

3. Henderson DA. Smallpox - the death of a disease: the inside story of eradicating a worldwide killer. Amherst, NY: Prometheus Books; 2009.

4. Yekutiel P. Lessons from the Big Eradication Campaigns. World Health Forum 1981: 2(4):465-490.

5. World Health Organization (WHO). The Work of WHO 1978-1979: Biennial Report of the Director-General to the World Health Assembly and to the United Nation. Geneva: WHO; 1980.

6. Birn A-E. The stages of international (global) health: histories of success or successes of history? Global Public Health 2009; 4(1):50-68.

7. Mills A. Mass campaigns versus general health services: what have we learned in 40 years about vertical versus horizontal approaches? Bulletin of the World Health Organization 2005; 83(4):315-316.

8. World Health Organization Association of Former WHO Staff (AFSM) Oral History Project. Transcript of an oral interview with Dr. Joshua Cohen. Moderated by Dr. Miriam Hirschfeld. Recorded on 16 July 2006, Jerusalem, Israel.

9. Cueto M. The origins of primary health care and selective primary health care. American Journal of Public Health 2004; 94(11):1864-1874.

10. Newell K. Selective primary health care: the counter revolution. Social Science and Medicine 1988; 26:903906.

11. Grant JP. Child survival and development revolution. Pediatrics in Review 1986; 8(6):163.

12. Werner D, Sanders D. Questioning the solution: the politics of primary health care and child survival. Palo Alto (CA): Healthwrights; 1997.

13. Bhattacharya S. The World Health Organization and global smallpox eradication. Journal of Epidemiology and Community Health 2008; 62:909-912.

14. Litsios S. The long and difficult road to Alma-Ata: a personal reflection. International Journal of Health Services 2002; 32(4):709-732.

15. Lhotska L. Whatever happened to Health for All? Ups and downs of protection of breastfeeding, regulation of transnational corporations and Health for All. Geneva: IBFAN-GIFA; 2008.

16. Report of the Unicef/WHO Inter-Secretariat Meeting, Geneva, 2-3 September, 1985. Box R.1048. File N69/83/2(26). Geneva, Switzerland: World Health Organization Archives; 1985.

17. Brooks R. Unicef, beware - dangerous shoals ahead: backgrounder \#287. Washington (D.C.): The Heritage Foundation; 1983.

18. Starrels J. The World Health Organization: resisting Third World ideological pressures. Washington (D.C.): The Heritage Foundation; 1985. 
19. Unicef-WHO Joint Committee on Health Policy, $23^{\text {rd }}$ Session, Progress Report on the Implementation of the Primary Health Care Approach, Geneva 1981, JC23/Unicef-WHO/81. Box R. 1047. File N69/ 83/2(23). Geneva, Switzerland: World Health Organization Archives; 1981.

20. Unicef-WHO Joint Committee on Health Policy, Draft Report, $27^{\text {th }}$ Session, 23-25 January 1989, Geneva, JC27/Unicef-WHO/89.14. Box R. 3520. File N69/ 83/2(27). Geneva, Switzerland: World Health Organization Archives; 1989.

21. Henderson DA. Smallpox eradication: a Cold War victory. World Health Forum 1998; 19:113-119.

22. Manela E. A pox on your narrative: writing disease control into Cold War history. Diplomatic History 2010; 34(2):299-323.

23. Venediktov D. Alma-Ata and after. World Health Forum 1998; 19(1):79-86.

24. Lown B. Prescription for survival: a doctor's journey to end nuclear madness. San Francisco: Berrett-Koehler Publishers; 2008.

25. Birn A-E. Marriage of convenience: Rockefeller international health and revolutionary Mexico. Rochester: University of Rochester Press; 2006. p. 244-245.

26. Keelan J. Biopolitics and the body politic: antivaccinationism in Canada from a historical perspective. MCIS (Munk Centre for International Studies) Briefings 2005; 3:78-98.

27. Needell J. The revolta contra la vacina of 1904: the revolt against "modernization" in Belle-Epoque Rio de Janeiro. In: Arrom S, Ortoll S, editors. Riots in the cities: popular politics and the urban poor in Latin America 1765-1910. Delaware, Maryland: SR Books; 1996. p. 155-193.

28. Meade TA. "Civilizing" Rio: reform and resistance in a Brazilian city, 1889-1930. University Park, Pennsylvania: State University Press; 1997.

29. Morbosidad y mortalidad por viruela en la Republica durante el año 1909. Boletín del Consejo Nacional de Higiene 1911; 6:536-606.

30. Amrith S. Decolonizing international health: India and Southeast Asia, 1930-65. Houndsmills, Basingstoke (UK): Palgrave; 2006.

31. Roy J. Smallpox zero: an illustrated history of smallpox and its eradication. Johannesburg: Nic Buchanan, Umlando Wezithombe, African Comic Production House; 2010.

32. Greenough P. Intimidation, coercion and resistance in the final stages of the South Asian Smallpox Eradication Campaign, 1973-1975. Social Science and Medicine 1995; 41(5):633-645.

33. Obadare E. A crisis of trust: history, politics, religion and the polio controversy in Northern Nigeria. Patterns of Prejudice 2005; 39(3):265-284.

34. Bhattacharya S. Expunging variola: the control and eradication of smallpox in India, 1947-1977. Hyderabad, India: Orient Longman; 2006.

35. Global Health Watch 2005-2006: an alternative world health report. London: People's Health Movement, Medact, GEGA, Zed Books; 2005.
36. Dobson MJ, Malowany M, Snow RW. Malaria control in East Africa: the Kampala Conference and the Pare-Taveta Scheme: a meeting of common and high ground. Parassitologia 1998; 40(1-2):149-166.

37. Arita I, Wickett J, Nakane M. Eradication of infectious diseases: its concept, then and now. Japanese Journal of Infectious Diseases 2004; 57:1-6.

38. Vastag B. The siren song of disease eradication: is it out of tune with the times? JAMA 2003; 289(9):10901091.

39. Goodman RA, Foster KL, Trowbridge FL, Figueroa JP, editors. Global disease elimination and eradication as public health strategies. Bulletin of the World Health Organization 1998; 76(Suppl. 2):p. 1-162.

40. Barrett S. Eradication versus control: the economics of global infectious disease policies. Bulletin of the World Health Organization 2004; 82(9):683-688.

41. Address by Dr. H Mahler, Director-General, World Health Organization on the Occasion of the Celebration of the $40^{\text {th }}$ Anniversary of WHO and $10^{\text {th }}$ Anniversary of the Declaration of Alma-Ata, During the $41^{\text {st }}$ World Health Assembly. Geneva 4 May 1988. Document DG/81.2 Rev.2 IV.7; WHA41/DIV/ 8. Box: Mahler Speeches, World Health Organization Library.

42. "World Health for All: To be!" Address by Dr. H Mahler. Director-General of the World Health Organization in presenting his report for 1986 to the $40^{\text {th }}$ World Health Assembly. Geneva, 5 May 1987. WHA40/DIV/4. p. 3.

43. Birn A-E, Pillay Y, Holtz TH. Textbook of international health: global health in a dynamic world. $3^{\text {rd }}$ ed. New York: Oxford University Press; 2009. Chapter 4 , especially.

44. Birn A-E. Gates' grandest challenge: transcending technology as public health ideology. The Lancet 2005; 366:514-519.

45. McCoy D, Kembhavi G, Patel J, Luintel A. The Bill and Melinda Gates Foundation's grant-making program for global health. The Lancet 2009; 373:16451653.

46. Guth R. Gates rethinks his war on polio. Wall Street Journal 23 April 2010. [artigo na Internet] 2010 [acessado 2010 maio 31]. Disponível em: http:// online.wsj.com/article/SB100014240527023033485045 75184093239615022.html?KEYWORDS=philanthrop

Artigo apresentado em 11/5/2010

Aprovado em 10/7/2010

Versão final apresentada em 11/9/2010 